\title{
PEMANFAATAN SAMPAH RUMAH TANGGA BERBASIS MASYARAKAT SEBAGAI MODEL PEMBERDAYAAN MASYARAKAT DI KELURAHAN LATUPPA KECAMATAN MUNGKAJANG KOTA PALOPO
}

\author{
Ishak ${ }^{1}$ Suwandi $\mathbf{N}^{2}$ \\ ${ }^{12}$ Prodi Kesehatan Masyarakat STIKes Mega Buana Palopo \\ ${ }^{1}$ ishaknurlang90@gmail.com 22nursalimsuwandi@gmail.com
}

\begin{abstract}
Produksi sampah setiap hari semakin meningkat seiring dengan bertambahnya jumlah produk dan pola konsumsi masyarakat(1). Dari 250 juta jiwa penduduk Indonesia dapat menghasilkan 151.192 ton per hari dengan kebiasaan orang Indonesia membuang sampahnya sembarangan sebanyak 70,31\%. Kesadaran masyarakat yang kurang untuk buang sampah pada tempatnya akan berakibat pada kurangnya partisipasi masyarakat untuk menjaga lingkungan. Kurangnya partisipasi masyarakat untuk mengikuti kegiatan bersama membersihkan lingkungan membuat sampah-sampah yang ada belum ditangani dengan baik. Tujuan dari penelitian ini adalah untuk mengetahui dan menyusun model pemberdayaan masyarakat sesuai kebutuhan masyarakat dalam mengelolah sampah rumah tangga. Penelitian ini yaitu menggunakan metode penelitian sosial Participatory Action Research (PAR). PAR terdiri dari tiga kata yang saling berhubungan satu sama lain. Ketiga kata tersebut adalah partisipasi, riset dan aksi. Peneliti melakukan beberapa tahapan yang dimulai dari pendidikan dan penyadaran yang dilakukan asyarakat terkait masalah sampah rumah tangga. Partisipasi dari masyarakat dibangun dengan melibatkan masyarakat yang ada di kelurahan Latuppa untuk melakukan pengolahaan sampah melalui pelatihan daur ulang sampah plastik menjadi bahan kerajinan rumah tangga dan pelatihan pengolahan sampah organik menjadi pupuk kompos. Dengan adanya pelatihan daur ulang sampah plastik menjadi barang kerajinan rumah tangga dan juga mengadakan pelatihan pembuatan pupuk kompos untuk sampah organik dapat merubah perilaku masyarakat untuk tidak membuang sampah disekitar pemukiman dan tidak membakar sampah di pekarangan. Adanya penyuluhan tentang sampah juga dapat menyadarkan masyarakat tentang pentingnya menjaga lingkungan.
\end{abstract}

Kata kunci: Pemanfaatan sampah; Pemberdayaan masyarakat; Sampah rumah tangga

\begin{abstract}
Waste production is increasing every day in line with the increasing number of products and consumption patterns of society(1). Of the 250 million inhabitants of Indonesia can produce 151,192 tons per day with the habit of Indonesians littering as much as $70.31 \%$. Lack of community awareness to dispose of trash in its place will result in lack of community participation to protect the environment. Lack of community participation to participate in joint activities to clean the environment makes the existing garbage has not been handled properly. The purpose of this research is to find out and arrange a community empowerment model according to community needs in managing household waste. This research is using the social research method Participatory Action Research. PAR consists of three words that are interconnected with one another. The three words are participation, research and action. Researchers carry out several stages starting from education and awareness carried out by the community related to household waste problems. Participation from the community was built by involving the community in Latuppa village to process waste through training on recycling plastic waste into household handicraft materials and training on processing organic waste into compost fertilizer. With the training in recycling plastic waste into household handicraft items and also conducting training in making compost for organic waste can change people's behavior to not throw garbage around the settlement and not to burn rubbish in the yard. The existence of counseling about waste can also make people aware of the importance of protecting the environment.
\end{abstract}

Keywords: Waste utilization; Community empowerment; Household waste 


\section{PENDAHULUAN}

Produksi sampah setiap hari semakin meningkat seiring dengan bertambahnya jumlah produk dan pola konsumsi masyarakat ${ }^{1}$. Dari 250 juta jiwa penduduk Indonesia dapat menghasilkan 151.192 ton per hari dengan kebiasaan orang Indonesia membuang sampahnya sembarangan sebanyak 70,31\%. Hal ini menjadikan Indonesia berada pada urutan ketiga tertinggi di dunia sebagai Negara terkotor setelah India dan China (World Bank)2.

Masalah timbulan sampah dibanyak negeri dan kota-kota terutama kota besar, bahkan sekarang hampir dimana-mana, menjadi agenda diskusi lingkungan yang tidak habis dibicarakan ${ }^{3}$. Misalnya di Kota Makassar, pada tahun 2017 volume sampah telah mencapai 1000-1200 ton per hari. Hal ini disebabkan karena kurangnya kesadaran masyarakat untuk mengolah (memilah) sampahnya secara mandiri, serta sistem pengelolaan sampah perkotaan/permukiman belum mendapat prioritas dalam pembangunan kota sehingga diperlukan kebijakan yang tepat agar sampah tidak menjadi bom waktu di masa mendatang. Oleh karena itu, salah satu upaya pemerintah yaitu dengan pengadaan bank sampah 4 .

Permasalahan sampah ini telah terjadi pula di kota Palopo, yakni terjadi penumpukan sampah dimana-mana. Rata-rata timbunan sampah di seluruh kota Palopo berkisar antara 3 sampai 3,7 ton /hari, sementara kapasitas angkut pelayanan hanya sekitar $40 \%$ atau hanya tersedia 25 truk sampah dan sekitar 250 orang sumber daya manusia ${ }^{5}$.

Keberadaan tempat pembuangan sampah atau TPS sangat diperlukan ditiap-tiap kota, kurangnya TPS dan armada pengangkut sampah menyebabkan penumpukan sampah di beberapa wilayah di kota Palopo khususnya wilayah kelurahan Latuppa. Namun bukan hanya permasalahan pada tempat pembuangan sampah atau TPS saja yang menjadi masalah utama, kurangnya kesadaran masyarakat untuk buang sampah pada tempatnya juga merupakan masalah. Masih banyak masyarakat yang membuang sampah dengan praktis di jalan, bahkan membuangnya langsung ke sungai ${ }^{5}$.

Kesadaran akan kebersihan harus dibangun dari diri sendiri. Seperti yang terjadi di Kelurahan latuppa, dimana wilayah ini merupakan salah satu objek wisata unggulan kota Palopo. Dari kegiatan pariwisata tersebut menyebabkan banyaknya kunjungan masyarakat yang akan berwisata disekitar sungai dan air terjun yang mana sering kali mereka membuang sampah secara sembarangan, tempat sampah yang kurang memadai sehingga timbulan sampah sulit untuk diatasi. Kesadaran masyarakat yang kurang untuk buang sampah pada tempatnya akan berakibat pada kurangnya partisipasi masyarakat untuk menjaga lingkungan. Kurangnya partisipasi masyarakat untuk mengikuti kegiatan bersama membersihkan lingkungan membuat sampah-sampah yang ada belum ditangani dengan baik $^{5}$.

Dari permasalahan-permasalahan yang terjadi terdapat salah satu upaya yang dapat dilakukan yaitu dengan mendaur ulang sampah melalui kegiatan pemberdayaan masyarakat. Program pemberdayaan melalui daur ulang sampah ini menjadi sangat penting dan strategis sebagai upaya meningkatkan kepedulian masyarakat dalam mengolah dan memanfaatkan sampah, terutama sampah rumah tangga.

Program pemberdayaan melalui daur ulang sampah ini menjadi sangat penting dan strategis sebagai upaya pembangunan lingkungan berbasis masyarakat, yaitu mengupayakan peran serta atau partisipasi masyarakat. Langkah ini bukan hanya dilakukan untuk mengurangi penumpukan sampah saja, namun juga untuk memberdayakan masyarakat agar peduli terhadap lingkungan. Pemberdayaan masyarakat ini dapat menangani penumpukan sampah sangat beragam, seperti mengolah cangkang telur menjadi sebuah lukisan, sampah plastik menjadi kerajinan tangan, hingga limbah organik menjadi pupuk kompos.

\section{METODE}

Penelitian ini menggunakan pendekatan PAR atau Participatory Action Research. PAR adalah metode penelitian aksi partisipatoris, yang bertujuan untuk mengidentifikasi rumusan masalah penelitian berdasarkan kebutuhan dari subyek yang akan diteliti ${ }^{6}$.

Hasil akhir dari penelitian ini adalah adanya perubahan bagi subyek sendiri, adanya aksi yang dilakukan sebagai bentuk rekomendasi penelitian PAR. Penelitian ini menarik, mengingat penelitian lainnya tidak berfokus pada subyek penelitian, melainkan pada keinginan di peneliti sendiri. Pada penelitian PAR, peneliti adalah fasilitator yang menggali bersama-sama subyek yang akan diteliti mengenai isu apa yang penting untuk diteliti berkaitan dengan subyek.

Penelitian ini diyakini sangat bermanfaat sekaligus sangat manusiawi. Sangat bermanfaat karena masyarakat subyek lah yang lebih mengetahui problem apa yangada di sekitar mereka, problem apa yang penting untuk di gali dan didalami serta dicari solusinya. Sedangkan peneliti "hanya" lah outsider yang belum tentu mengetahui dengan baik dan akurat mengenai problem di sekitar subyek penelitian. Penelitian PAR dianggap lebih manusiawi, karena subyek dihargai harkat dan martabatnya sebagai manusia, bukan sekedar informan dan 
responden yang diambil datanya untuk dimanfaatkan sebagai data yang „mati“. Subyek adalah agen yang aktif yang dilibatkan dalam proses penelitian bahkan dilibatkan dalam membawa perubahan di Masyarakatnya setelah penelitian selesai dilakukan.

PAR berbeda dengan teknik problem-solving sebagaimana yang dilakukan orang sehari-hari karena PAR mengandung unsur penelitian. Pendekatan ini dipilih karena sesuai dengan karakteristik subyek dampingan yaitu masyarakat Kelurahan Latuppa yang perlu dilatih dan di dampingi dalam mengatur dan memanajemen sampah dengan langkah awal yaitu membangun kesadaran masyarakat tersebut.

\section{HASIL}

\section{Pelaksanaan Participatory Action Research (PAR)}

\section{Perencanaan Penelitian}

Perencanaan dalam program PAR disusun secara partisipasif dengan melibatkan tokoh pemuda dan aparat desa dalam hal ini ketua RW dan RT masing masing. Langkah awal dalam perencanaan penelitian ini yaitu melakukan identifikasi masalah masalah terkait sampah dan alternative pemecahan masalah. Adapun masalah yang ditemukan yaitu

a. Kurangnya Kesadaran Masyarakat dalam Pengelolahan Sampah.

Sampah memang masih menjadi permasalahan yang ada di setiap daerah, karena setiap rumah tangga dan segala aktivitas manusia yang hidup akan menghasilkan sampah ${ }^{3}$. Sampah di Kelurahan Latuppa masih menjadi masalah yang belum terselesaikan sampai sekarang ini. Banyak perilaku dari masyarakat sendiri yang belum menyadari pentingnya mengelolah sampah khususnya sampah rumah tangga, masih terdapat sebagian masyarakat yang membuang sampah sembarang di sungai dan sebagian masyarakat juga membakar sampah yang ada di pekarangan rumah yang dapat berdampak pada pencemaran udara.

Sampah menjadi permasalahan di Kelurahan Latuppa disebabkan juga karena wilayah tersebut merupakan salah satu tempat wisata yang banyak dikunjungi warga di akhir pekan dan hari libur sehingga menghasilkan volume sampah yang jumlahnya tidak sedikit dari pengunjung yang datang berwisata.

b. Kurangnya Pengetahuan dan Keterampilan Masyarakat dalam Mendaur Ulang Sampah.

Masyarakat di Kelurahan Latuppa masih belum melakukan kegiatan daur ulang sampah. Hal ini dapat dilihat dari perilaku masyarakat yang masih membuang sampah rumah tangga di sungai dan sebagian juga masih melakukan pembakaran sampah di pekarangan rumah.
Penyebab lainnya karena masih sangat minimnya edukasi terkait daur ulang sampah dan masih kurang sarana dan prasana yang mendukung seperti belum tersedianya tempat pemilahan sampah organik dan non organik dan kendaraan untuk pengangkut sampah ke tempat penampungan akhir (TPA).

c. Belum optimalnya sosialisasi pembentukan Bank Sampah yang dilakukan oleh pihak pemerintah terkait dalam hal ini Dinas Lingkungan Hidup.

Di Kelurahan Latuppa sebelumnya sudah pernah mendapatkan sosialisasi terkait pembentukan Bank Sampah di masyarakat, namun hasil dari kegiatan ini masih belum optimal karena kurangnya minat dan partisipasi masyarakat dalam pembentukan Bank Sampah tersebut sehingga pembentukan program tersebut tidak terlaksana. Sampah masih dipandang oleh masyarakat sebagai barang yang tidak bisa digunakan lagi dan tidak bernilai ekonomis.

2. Sosialisasi dan Focus Group Discussion (FGD) Pada Masyarakat dengan Memperkenalkan Program Pengelolahan Sampah

Dalam kegiatan ini peneliti mengumpulkan masyarakat di gedung sekertariat Ikatan Pemuda Latuppa (IPLAT). Dalam pertemuan ini dilakukan sosialisasi dengan memaparkan materi terkait sampah dan cara penanggulangannya kepada masyarakat, kemudian dilanjutkan dengan kegiatan Focus Group Discussion (FGD) dengan tujuan untuk memperkenalkan program daur sampah dan sekaligus menggali informasi terkait kebutuhan untuk pelaksanaan program.

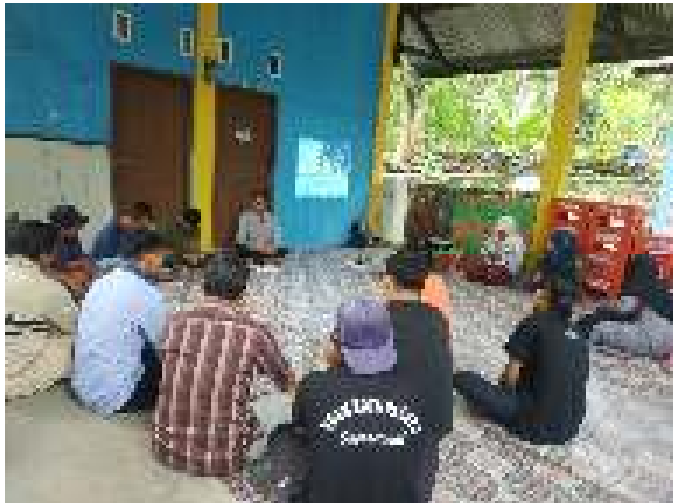

Gambar 1. Pelaksanaan Sosialisasi dan Focus Group Discussion (FGD)

Dari hasil FGD dengan masyarakat setempat maka didapatkan hasil assessement beberapa kegiatan yang ditawarkan oleh peneliti sebagai bagian dari program kegiatan dalam penelitian ini yaitu sebagai berkut: 
Tabel 1. Hasil Kesepakatan Kegiatan Pelatihan Daur Ulang Sampah

\begin{tabular}{|c|c|c|c|}
\hline \multirow[b]{2}{*}{ No } & \multirow[b]{2}{*}{ Jenis kegiatan } & \multicolumn{2}{|c|}{ Alternatif jawaban } \\
\hline & & Berminat & $\begin{array}{l}\text { Tidak } \\
\text { berminat }\end{array}$ \\
\hline 1 & $\begin{array}{l}\text { Pelatihan pembuatan } \\
\text { tikar kemasan plastik }\end{array}$ & Ya & \\
\hline 2 & $\begin{array}{l}\text { Pelatihan pembuatan } \\
\text { piring/bosara gelas } \\
\text { plastic }\end{array}$ & Ya & \\
\hline 3 & $\begin{array}{l}\text { Pelatihan pembuatan } \\
\text { lampion gelas plastik }\end{array}$ & Ya & \\
\hline 4 & $\begin{array}{l}\text { Pelatihan pembuatan } \\
\text { keranjang belanjaan } \\
\text { gelas plastik }\end{array}$ & Ya & \\
\hline 5 & $\begin{array}{l}\text { Pelatihan pembuatan } \\
\text { pupuk kompos sampah } \\
\text { organik }\end{array}$ & Ya & \\
\hline 6 & $\begin{array}{l}\text { Pelatihan pembuatan } \\
\text { hanger kerudung dan } \\
\text { hiasan dinding }\end{array}$ & & Tidak \\
\hline 7 & $\begin{array}{l}\text { Pelatihan pembuatan } \\
\text { tempat sampah dari } \\
\text { gelas plastic }\end{array}$ & & Tidak \\
\hline 8 & $\begin{array}{l}\text { Pelatihan pembuatan } \\
\text { kursi dari botol bekas }\end{array}$ & & Tidak \\
\hline 9 & $\begin{array}{l}\text { Pelatihan pembuatan } \\
\text { bunga plastik }\end{array}$ & & Tidak \\
\hline
\end{tabular}

Berdasarkan dari hasil urutan jenis kegiatan sesuai dengan minat dari masyarakat, dari hasil FGD ini tidak semua kegiatan dapat dilaksanakan karena keterbatasan waktu, alat dan bahan. Maka dirumuskan beberapa kegaiatan yang dapat dilakukan sebagai berikut:

a. Pelatihan pembuatan tikar dari kemasan plastic

b. Pelatihan pembuatan piring/bosara dari gelas plastic

c. Pelatihan pembuatan lampion dari gelas plastic

d. Pelatihan pembuatan keranjang belanjaan

e. Pelatihan pembuatan pupuk kompos

Dalam merencanakan rencana aksi dan jadwal kegiatan dalam penelitian ini, semua hambatan maupun kendala yang kemungkinan akan muncul telah didiskusikan peneliti bersama masyarakat yang terlibat dalam kegiatan aksi.

Dari hasil FGD dengan masyarakat, telah disepakati beberapa kegiatan berupa pelatihan pengolahan sampah baik organik maupun non organik. Adapun langkah awal dalam kegiatan ini, peneliti bersama masyarakat menyepakati untuk melakukan bakti sosial berupa kerja bakti pengumpulan sampah plastik sekaligus melakukan pemilahan sampah untuk digunakan sebagai bahan utama dalam kegiatan pelatihan.

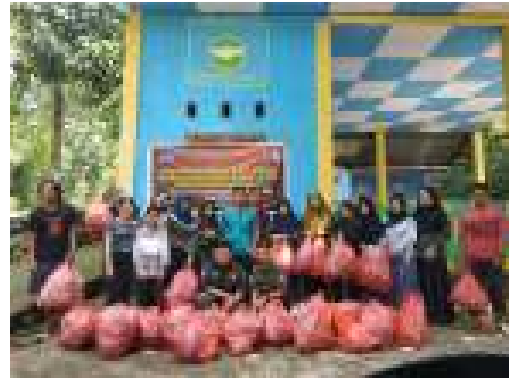

Gambar 2. Pelaksanaan Bakti Sosial Bersama Masyarakat

3. Program Pelatihan

a. Pelatihan Pembuatan Tikar dari Kemasan Plastik Kopi Sachet.

Tikar adalah hasil anyaman yang biasanya dipakai sebagai alas untuk duduk atau tidur, dalam pelatihan ini dengan mengajarkan kepada peserta untuk membuat tikar dari bungkus kemasan yang terbuat dari bahan plastik, misalnya bungkus kopi.

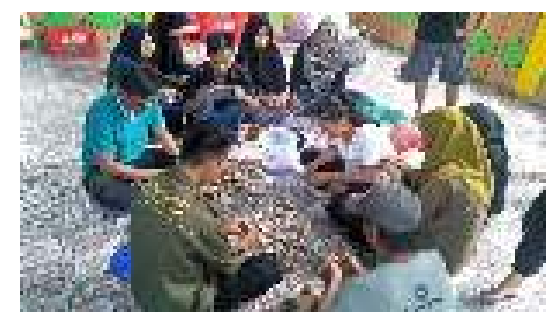

Gambar 3. Pelatihan Pembuatan Tikar dari Kemasan Kopi Sachet

b. Pelatihan Pembuatan Bosara

Bosara adalah sebuah wadah/tempat yang digunakan untuk menyajikan kue dalam sebuah acara atau pesta di suku Bugis - Makassar.

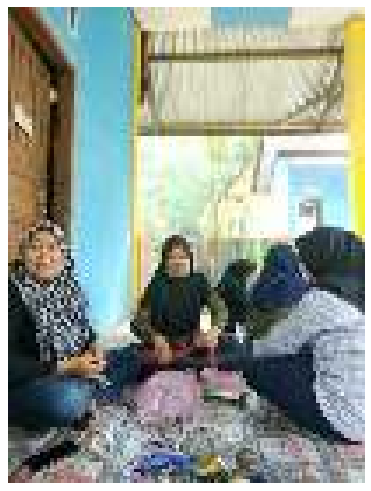

Gambar 4. Pelatihan Pembuatan Bosara

c. Pelatihan Pembuatan Lampion

Lampion secara umum dikenal sebagai sejenis lampu yang biasanya terbuat dari kertas dengan lilin di dalamnya. Pada pelatihan ini, lampion yang dibuat merupakan hasil olah dari sampah gelas plastik sehingga menjadi dekorasi 
lampu hias. Alat dan bahan yang digunakan sangatlah mudah didapatkan.

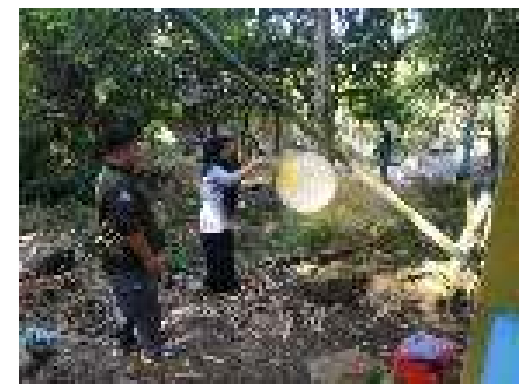

Gambar 5. Pelatihan Pembuatan Lampion (Proses Pewarnaan Lampion)

d. Pelatihan Pembuatan Keranjang Belanja

Keranjang belanja dikenal sebagai alat yang disediakan oleh toko, terutama supermarket, yang digunakan oleh pelanggan sebagai tempat membawa barang belanjaan dari dalam toko pada saat berbelanja.

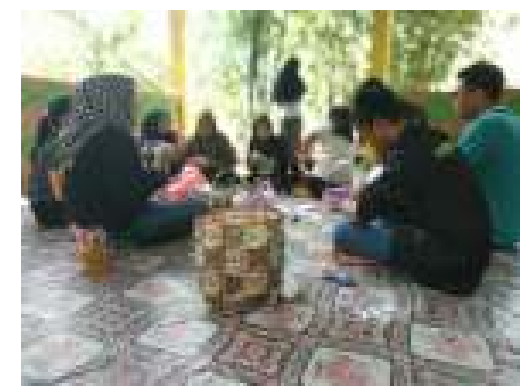

Gambar 6. Pelatihan Pembuatan Keranjang Belanja

e. Pelatihan Pembuatan Pupuk Kompos (Komposting) dari Sampah Organik

Sisa sisa makanan hasil buangan dari rumah tangga biasanya hanya langsung dibuang ke sungai yang tentunya dapat mencemari badan air. Pelatihan ini bertujuan untuk memberikan pelatihan daur ulang sampah organik sisa - sisa makanan dan limbah dari rumah tangga. Sisa sisa makanan dikumpulkan dalam wadah kemudian diolah menjadi pupuk kompos. Hasil olahan ini masyarakat dapat gunakan untuk pupuk tanaman mereka dan sebagian bisa dijual ke pedagang pupuk.

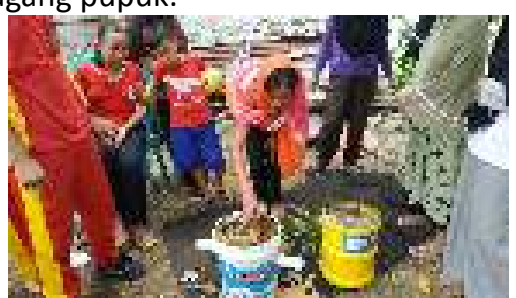

Gambar 7. Pelatihan Pembuatan Pupuk Kompos/Komposting

\section{PEMBAHASAN}

Penelitian yang dilakukan di Kelurahan Latuppa mengkaji tentang masalah pengelolahan sampah yang belum ditangani secara baik. Banyak faktor yang menjadi penyebab timbulnya masalah lingkungan terkait sampah .Di setiap rumah tangga belum terdapat tempat pembuangan sampah sementara dan juga disekitar pemukiman warga masih banyak lahan kosong sehingga masyarakat sudah terbiasa membuang sampah dilahan tersebut. Dan juga lokasi Kelurahan Latuppa yang agak jauh dari pusat kota yang menjadi hambatan sarana mobil pengangkut sampah untuk menjangkau kelurahan ini. Untuk itu peneliti mencoba menggali dan menganalisis masalah tersebut melalui pendekatan partisipasi masyarakat.

Pengelolahan lingkungan hidup harus berkesinambungan untuk peningkatan kesejahtraan hidup manusia yang ditunjang dari pembangunan lingkungan yang serasi dan seimbang. Melalui pengolahan sampah yang berkelanjutan ini diharapakan dapat memberikn dampak positif bagi kesejahtraan manusia. Dengan mengolah sampah plastik menjadi barang yang bernilai ekonomis dan menjadi barang yang dapat digunakan kembali diharapkan mampu mengurasi penumpukan sampah di sekitar pemukiman masyarakat dan di tempat pembuangan akhir. Dengan mengolah sampah plastik juga dapat mengurangi dampak kerusakan lingkungan. Masyarakat juga tidak lagi membuang sampah kesungai. Sampah yang dibuang ke sungai dapat menurunkan kualitas air dan juga dapat mempengaruhi kesuburan tanah. Masyarakat tidak lagi membakar sampah plastik yang menumpuk sehingga dapat mengurangi pencemaran lingkungan khususnya pencemaran udara.

Dalam penelitian ini melihat partispasi masyarakat dalam beberapa kegiatan yang dilakukan peneliti dan juga berdasarkan hasil Focus Group Discusion (FGD) Langkah aksi yang pertama dilakukan dalam kegiatan pemberdayaan masyarakat dalam pemanfaatan sampah rumah tangga yaitu dengan memberikan penyuluhan tentang pentingnya pengolahan sampah pada saat pertemuan disekertariat IPLAT yang dihadiri oleh sebagian masyarakat karena mayoritas masyrakat setempat bekerja pada siang hari seperti bertani sehingga sebagian masyarakat banyak yang berhalangan hadir. Kegiatan ini untuk peningkatan pengetahuan dan kesadaran masyarakat dalam pelestarian lingkungan.

Pada tahap selanjutnya yaitu dengan memberikan pelatihan daur ulang sampah plastik menjadi barang yang dapat dimanfaatkan kembali dan bernilai ekonomis. Kegiatan ini untuk memberikan pengetahuan dan keterampilan kepada peserta pelatihan. Dengan adanya kegiatan pelatihan 
daur ulang sampah ini diharapkan masyarakat dapat menjadi lebih mandiri dalam pengolahan sampah rumah tangga. Program pemberdayaan daur ulang sampah dapat menjadi alternatif yang strategis untuk meningkatkan kepedulian masyarakat dalam mengolah sampah ${ }^{7}$. dengan adanya program pelatihan daur ulang sampah ini dapat memotivasi mengurangi volume sampah saja. Selain itu juga dilakukan kegiatan pelatihan pembuatan pupuk kompos (komposting) untuk pengolahan sampah organik. Sampah organik yang diolah menjadipupuk kompos dapat digunakan untuk tanaman masyarakat.

\section{SIMPULAN DAN SARAN}

Dengan adanya pemberdayaan yang melibatkan masyarakat melalui kegiatan pelatihan daur ulang sampah plastik menjadi barang kerajinan rumah tangga dan juga mengadakan pelatihan pembuatan pupuk kompos untuk sampah organik dapat merubah perilaku masyarakat untuk tidak membuang sampah disekitar pemukiman dan tidak membakar sampah di pekarangan.

Adanya penyuluhan tentang sampah juga dapat menyadarkan masyarakat tentang pentingnya menjaga lingkungan. Dan selanjutnya di harapkan terbentuk kelompok peduli lingkungan yang dapat menggerakkan masyarakat sehingga masyrakat mampu mengelolah sampah secara mandiri.

\section{DAFTAR PUSTAKA}

1. Sulistiyorini NR, Darwis RS, Gutama AS. Partisipasi Masyarakat Dalam Pengelolaan Sampah Di. Share masyarakat untuk ikut berpartisipasi melestarikan lingkungan (Hadi, Achmad Serudji)(8). Kegiatan daur ulang sampah palstik juga dirasakan dapat menambah penghasilan dari hasil penjualan produk daur ulang yang dihasilkan sehingga manfaat yang dirasakan bukan hanya

Soc Work. 2015;5(1):71-80.

2. Jastam MS. Pemberdayaan Masyarakat Melalui Pengelolaan Sampah (Studi Kasus di Bank Sampah Pelita Harapan, Kelurahan Ballaparang, Kecamatan Rappocini, Makassar). 2015;1 No.1.

3. Kementrian Lingkungan Hidup RI. Buku Panduan Mengelola Sampah Rumah Tangga Dengan Prinsip 4R (Reduce, Reuse, Recycle, Replant). Riau; 2007.

4. Hasanuddin M. Sampah Di Makassar 1.000-1.200 Ton Per Hari [Internet]. 2017. Available from: https://makassar.antaranews.com/berita/79994/s ampah-di-makassar-1000-1200-ton-per-hari

5. Dinas Lingkungan Hidup Kota Palopo. Data Sampah Kota Palopo. 2019.

6. McTaggart R. Action Research: A Short Modern History. Victoria: Deakin University; 1991.

7. Purbasari N. Pemberdayaan Masyarakat Melalui Kegiatan Daur Ulang Sampah Plastik (Studi Kasus Pada Komunitas Bank Sampah Poklili Perumahan Griya Lembah Depok Kecamatan Sukmajaya Kota DepokJ. Universitas Islam Negeri (UIN) Syarif Hidayatullah Jakarta; 2014.

8. Kasim SS. Pemberdayaan Ekonomi Kreatif Melalui Daur Ulang Sampah Plastik (Studi Kasus Bank Sampah Berlian Kelurahan Tangkerang Labuai). J Al-lqtishad, Ed 12. 2016;I:1-19. 